\title{
Why do Trade Unions Engage in Wage Coordination Although It Does Not Work? Evidence from the German Metal Sector
}

\author{
Martin Seeliger, University of Flensburg, Germany
}

\begin{abstract}
The article addresses the following puzzle: if, as it appears, wage coordination under the European Monetary Union is unlikely to succeed, why do European trade unions continue to pursue it? The article examines German metal-sector trade unions' ongoing participation in wage-coordination initiatives within the Eurozone. It argues that their participation can be explained by two factors a decoupling of talk and action, as two complementary types of organisational output, and the reframing of wage coordination as an activity that will pay off in the distant future.
\end{abstract}

\section{KEYWORDS}

Wage coordination; IG Metall; IndustriALL; collective bargaining; Eurozone; trade unions

\section{Introduction}

While undoubtedly beneficial in certain regards, European integration has created many challenges for trade unions, one of which is the European Monetary Union (EMU). With jurisdiction over monetary policy relocated from the national to the EU level, wage policy has become the most important means through which to avoid downward competition and adjust national inflation rates. As a consequence, trade unions have been burdened with increased political responsibility for macroeconomic stability. Only if nominal unit labour costs (NULC) develop consistently in all EMU countries can stable growth be maintained. As a result, it has become necessary to coordinate wages within the Eurozone.

Following Wolfgang Streeck (2015: 8), we take up the argument that in order to make sense of the current crisis in the relationship of capitalism and democracy within the EU, ${ }^{1}$ a macrosociological perspective on the interdependence between the political economies of European countries is needed. Due to the particular multi-level character of the EU's political system, however, it is necessary to complement this perspective with a meso- and micro-sociological focus on the interplay of European Monetary Union (macro-level), wage developments in the German metal sector (meso-level) and processes of collective bargaining coordination (micro-level).

After about twenty years of European labour unions' attempts to achieve bargaining outcomes

\footnotetext{
${ }^{1}$ It is important to note that, due to the particular focus on Germany in the context of the EU, statements and conclusions about the role of trade unions under democratic capitalism remain limited to export-sector organisations from the countries of the Global North. For a comprehensive perspective on labours' role in the Global South see Webster, Lambert and Bezuidenhout (2008). However, as these dynamics are contributing to the macroeconomic asymmetries within the Eurozone, the argument ultimately comprises the overall relationship between capitalism and democracy.
} 
consistent with the "Golden Rule" - that is, to keep up with inflation and productivity increases it has become apparent that these attempts suffer from a number of weaknesses that make it highly unlikely that such coordination will succeed (Höpner, 2013). Why, then, do European trade unions keep on trying?

To solve this puzzle, the article proposes a theoretical framework developed from two strands of literature, namely pragmatist organisation studies (Ansell, 2011) and neo-institutionalism (Brunsson, 1989). Most literature on European wage coordination is quantitative and/or theoretical. By adopting a qualitative approach, this article demonstrates that trade unions interpret wage coordination not as an immediate means to achieve the Golden Rule, but as a way to establish the European arena as the locus of wage negotiation in the future.

The next section will give an overview of the problems of wage coordination under the EMU from the perspective of political economy, with a particular emphasis on the role of trade unions. This particular focus is justified by the fact that initiatives on wage coordination are run by trade unions attempting to develop joint wage demands. The following section sums up the theoretical premises assumed when analysing trade union politics from an organisational perspective, before the fourth section presents the respective empirical findings. The next section then proposes an explanation for the puzzle of why trade unions engage in wage coordination initiatives, although they systematically fail to achieve their nominal aim. This paves the way for a final look at the macro-micro dynamics of wage coordination under the EMU in particular and European integration in general.

\section{International Coordination of Wage Policy under the EMU}

\section{Macroeconomic implications of wage policy under the EMU}

Collective bargaining lies at the core of trade union responsibilities. In market economies, such bargaining usually takes place between business associations or management on one side and trade unions or company-level bodies of worker representation on the other. Hall (2007: 69) has identified the central challenge of collective bargaining as "the wage problem". In order to protect profits and secure future investments, capital attempts to keep wage developments moderate. Labour, in contrast, attempts to achieve higher wages in order to obtain a greater share of societal wealth. Apart from such immediate member-driven interests, another important aspect of wage policy is macroeconomic stability, which, from a national perspective, depends on the balance of trade.

Because the common currency prevents European Union (EU) member states from using their central banks to even out differences in inflation, it has become necessary to coordinate price levels differently. Low wages, by increasing competitiveness in the export sector, can stimulate national economic activity and improve the trade balance. High wages, in contrast, increase national demand, which can hurt the trade balance. As a result, wage policy is seen as a means through which to manage national inflation rates.

\section{Wage coordination under the EMU}

While the above explanation focuses on the macroeconomic effects of wage policy, trade unions consider the issue from another perspective. Since the 1960s, European metal-sector trade unions have been aware of the threat of increased competition through parallel production and relocation, and in the 1970s they established informal exchange rounds on wage coordination (Pen, 1964; Glassner and Pochet, 2011: 12). With collective bargaining at the core of national trade unions' 
political responsibilities, initiatives of international wage coordination have over the years developed into an integral part of European-level trade unionism. This is not only due to their (alleged) economic impact, but also to the fact that they provide a platform for regular cooperation and thus also a repertoire from which to construct and develop a common identity within the broader framework of a European Social Model.

The increased political salience of wage coordination was reflected by the European Metalworkers Federation's (EMF) introduction of the so-called Golden Rule in the mid-1990s. According to this rule, wage demands should at least equal growth in terms of inflation ${ }^{2}$ and productivity development. ${ }^{3}$ Only if nominal regional wage increases equal the productivity development plus the target inflation rate could transnational downward competition be avoided and macroeconomic stability maintained. ${ }^{4}$

In order to operationalise this coordination, the European Metalworkers Federation established a joint database through Eucob@n, the European Collective Bargaining Network. This database contains collective bargaining outcomes as well as general information about national wage-setting institutions throughout the EU. The EMF's Collective Bargaining Committee has also held regular discussions on the issue and sent representatives to local bargaining negotiations. With the merger of European labour federations from the energy and textile sector into IndustriALL in late 2012, the federation announced that wage-coordination initiatives would gradually be expanded to other sectors as well.

The following section summarises the academic literature on the European wage coordination.

\section{European wage coordination: the academic literature}

As a central aspect of European-level trade union cooperation, wage coordination has been the subject of a number of studies over the last two decades. While some of the literature has emphasised the possibility of and need for wage coordination (e.g. Schulten, 2001), from the very beginning a number of empirical studies have downplayed - but not rejected - the likelihood of success (Traxler, 2000; Traxler and Brandl, 2000; Erne, 2008; Glassner, 2009; Johnston, 2009; Glassner and Pernicka, 2014). Three theoretical arguments can be found in the literature to explain why initiatives for European wage coordination have not proven effective in preventing downward competition or maintaining macroeconomic stability.

The first involves unions' strategic attempts to maintain competitiveness. Unions sometimes negotiate for lower wages than their bargaining strength would allow them to obtain in order to secure jobs and promote economic growth. As Höpner (2013: 6) notes, the EMU has made this

\footnotetext{
${ }^{2}$ For the Eurozone, this is the target inflation rate of approximately 2 per cent set by the European Central Bank.

3 The coordination rule suggested by the EMF can be interpreted in different ways. Based on our information, productivity growth refers to each country's forecasted productivity gains for the entire national economy in the given year. It can, however, be argued that one could achieve more stable results by considering trend productivity developments.

${ }^{4}$ Under the conditions of economic asymmetry that exist within the Eurozone, this model of coordination appears to be insufficient in tackling discrepancies in wage developments that have accumulated over the past few decades. Because adherence to the coordination rule would only secure synchronic wage developments, a gradual equalisation of wages is unlikely. In order to achieve equal wages, redistribution in terms of competitiveness would seem necessary. Such a redistribution could occur through higher inflation in countries with a strong foreign trade balance (Watt, 2011).
} 
strategy even more attractive to trade unions. In order to maintain competitiveness, trade unions can engage in strategic alliances with employers and/or business associations at both company and sectoral levels.

The second involves the heterogeneity of national wage-setting systems within the Eurozone. As Höpner (2013, 2014b) and Höpner and Lutter (2014) have noted, wage-setting institutions differ across EU countries. The literature identifies four central differences (Schulten, 2004): the percentage of workers and business associations subject to collective bargaining; concrete wagesetting procedures; the degree of institutional coverage through the state; and differences in production systems, including the branches of industry in which the various countries are specialised (Streeck, 2005).

The third argument involves differences in institutional frameworks among EU countries. While the Agenda 2010 reforms introduced by the Schröder government have significantly weakened German trade unions' bargaining position, the austerity measures imposed on other countries by the Troika ${ }^{5}$ have had an even greater impact on their unions' bargaining power. In order to increase the national competitiveness of so-called crisis countries, the Troika has interfered with national wage-setting procedures by enforcing public-sector cuts and lowering the minimum wage (Schulten and Müller, 2013). In recent years, the Troika has recommended changes to collective bargaining in two-thirds of EU member states. For instance, in order to increase their national competitiveness Belgium, Spain and Italy have been called on to decentralise bargaining procedures. The Troika has also required political reforms as a condition for financial support in Portugal, Cyprus, Hungary and, most prominently, Greece.

As Höpner and Seeliger (2017) have shown, wage dynamics have repeatedly failed to conform to the Golden Rule since the introduction of the Euro. Between 1999 and 2008, the increase in national unit labour costs in the eleven primary Eurozone countries exceeded wage increases by an average of 2.2 per cent, but since the crisis they have fallen short by an average of 8.7 per cent (Höpner and Seeliger, 2017: 9). Interestingly, a diagnosis - according to which a divergence in price-competitiveness would have had to be corrected by inducing a balanced wage-development - is shared across the spectrum of Keynesian as well as Neoclassical economics (Flassbeck and Lapavitsas, 2015; Sinn, 2015; Horn, 2017). Despite their differing theoretical paradigms, all three authors agree that macroeconomic instabilities resulting from German surpluses have prevented a state of macroeconomic stability.

Although trade unions rhetorically acknowledge the general need for bargaining coordination across the EMU, their ambitions have not been successfully translated into practice. Since the outcomes of wage coordination are mostly measured quantitatively, interpretations of the results are mostly limited to more or less abstract references to the framework conditions identified above. This study attempts to shed light on the dynamics of wage coordination from a qualitative perspective by pursuing the following research question: Why do trade unions persist in these attempts if they are unlikely to succeed?

\section{Theoretical Framework}

After sketching out the macrosocial framework for political action in the field of collective bargaining, this section aims to clarify our premises with regards to the (inter-)organisational micro-

${ }^{5}$ The Troika is a conglomerate of the European Commission, the European Central Bank and the International Monetary Fund, responsible for imposing austerity measures on national governments within the Eurozone. 
level. It is commonly believed that the task of trade unions is to represent the interests of the working class. While broadly true, from the perspective of political sociology this view requires further analysis. As organisations, trade unions are, at least to some degree, dependent on the interests of their members. Accordingly, regional, national, political and sectoral alliances demarcate the lines along which trade unions distinguish themselves from each other. The core business of trade unions is collective bargaining. So whose interests do trade unions represent in this field?

In practice, both trade union members' immediate interests (i.e. long-term job security) and the interests of the working class as a whole (i.e. avoiding downward competition) are reference points in trade union politics. Accordingly, collective bargaining is more difficult under the condition of international competition. Trade unions may promote international wage coordination for four reasons. The first is the desire to promote material redistribution (interest-based explanation; Erne, 2008). The second is mutual identification and international solidarity (identitybased explanation; Hyman, 2002). Third, once coordination incentives have been established, participating actors face normative pressure from each other (normative explanation; Pernicka and Glassner, 2014). Finally, the initiative of an organisational sub-group could produce and/or perpetuate such an engagement (sub-group-based explanation; Schmitter and Streeck, 1999).

Considering that trade unions mediate between two general goals - representing the interests of their members and promoting more general class interests - an explanation of international wage coordination based solely on rational action according to one particular goal seems unrealistic (Joas and Beckert, 2001). Instead, this article combines two strands of theory to account for trade unions' four reasons for promoting such coordination: pragmatism and neo-institutionalism. Pragmatism helps us understand actors' capacity to develop shared interests through cooperation, while neoinstitutionalism helps us understand how those actors decouple talk from action in order to meet incompatible expectations.

\section{Bargaining coordination as mutual meaning creation}

The point of departure taken in this study is informed by pragmatism, insofar as we aim to understand how actors establish shared meanings to communicate and coordinate political action (Mead, 1934: 254). To analyse political phenomena, Sabel and Zeitlin (2012) propose a twofold point of departure: strategic uncertainty (actors do not know, at least in the medium term, what is best for them); and a focus on constellations shaped by a polyarchic or multi-polar distribution of power between the actors involved. In this sense, Platzer (2002) identifies European-level trade union organisations as "social laboratories" in which new approaches to European problems are developed. The construction of political positions largely consists of "creative adjustment" (Overdevest, 2011: 539) and "learning through surprise" (Overdevest and Zeitlin, 2012: 280) within a process "of refining values and knowledge" (Ansell, 2011: 12).

Because the practice of European trade union representative work largely consists of mobilising political actors for common projects, it can be expected that images of common projects will be drawn upon to create a shared symbolic frame of reference (Ansell, 1997). By establishing this framework, European trade unionists perceive "the possibility ... of building a bridge between effective responses to urgent problems and the ultimate elaboration of a new form of democratic accountability that can take uncertainty in stride" (Sabel and Zeitlin, 2012: 424). Because the common pursuit of a generally shared class interest requires deliberation among the actors involved - mainly political parties, civil society organisations, and trade unions - a joint vision of the future thus becomes a powerful tool for mobilisation.

Based on these examples, we can conclude that in order to justify wage-coordination initiatives 
as a general class interest, ongoing exchange among national representatives must shape the framework conditions under which a mutual identification can emerge. Through such mutual identification, coordination can be established as a common symbolic framework that "links groups across similar positions" (Ansell, 1997: 364) and thus generates a sense of community among actors as a platform and reference frame for joint political action.

\section{Talk-action discrepancies in international trade union coordination}

The neo-institutionalist perspective, which investigates how organisations can deal with normative pressures without openly opposing them, helps us understand how wage-coordination initiatives persist under adverse conditions. Inspired by March and Olsen (1979) and Meyer and Rowan (1977), Nils Brunsson (1989) has emphasised the importance of actors' creative recombination of various forms of organisational outputs in order to connect contradictory goals within a single coping strategy.

In his study of municipal bureaucracies in Sweden, Brunsson (1989) gained fundamental insights into how organisations deal with contradictory external demands. He rejected the widespread assumption that individual and collective actors choose their actions according to coherent principles. Instead, Brunsson claimed, organisations employ different forms of organisational output (decision, talk and action) to meet contradictory demands without endangering their own internal cohesion. This decoupling of talk and action can, among other spheres, be observed in the context of global governance: "One of the main problems of contemporary global governance is ... the growing gap between international norm acceptance and recognition, on the one hand, and rule compliance, on the other" (Risse, 2004: 305; also see Krassner, 1999).

In our context, a national trade union could act with its national frame of reference in mind while rhetorically addressing an international audience in order to avoid sanctions from both its own members and unionists in other countries. Trade unions can employ a combination of talk and action to pursue both their own particular interests (whether of elite trade union leaders or of the entire membership) or the interests of other unions (or of the working class as a whole), at least in the short or medium term.

\section{Wage coordination between pragmatism and decoupling}

A rational model of action, according to which actors follow fixed preferences, cannot explain the fact that unions have consistently failed to achieve wage coordination despite their consistent commitment to that goal for the last fifteen years. But an action-theoretical model based on elements from pragmatism and neo-institutionalism can. Pragmatism is sensitive to changes in interests that may occur over the course of time as well as creative problem-solving, and neoinstitutionalism helps us understand why actors may talk and act in contradictory ways. Having laid this groundwork, the following section introduces the methodological design of the study.

\section{Research Design and Methodology}

This article focuses on the German economy because of the importance of that country's wage developments in the Eurozone (Flassbeck and Spieker, 2010). More specifically, it focuses on the German metal sector because its products contribute to Germany's positive foreign trade balance. Under the condition of strong international competition in export industries, trade unions in export-oriented sectors finds themselves in a particularly difficult situation (Hancké, 2013, 2014). The article covers the period from 1998 (when the conversion rates between the currencies of the 
first eleven EMU member states and the Euro were set) to 2013 (when the bargaining rounds before the interviews were conducted).

Within the multi-level system of European labour relations, wage coordination is mainly negotiated between European-level sectoral federations and the national headquarters of sectoral trade unions (Marginson and Sisson, 2004). This article draws on qualitative data gathered in interviews with officials from the metal sector, and focuses on the interplay between these two levels based on the cooperation between German IG Metall and the European-level federation IndustriALL. As the puzzle addressed by this article is based on the question "Why do trade unions conduct wage coordination, although it does not work?" the particular research strategy focuses not on the comprehensive constellation of wage setting, which would also include business associations, companies and the state, but the cooperation of IG Metall and IndustriALL as the most significant case of trade-union-run wage coordination. In line with the action-theoretical framework described above, it attempts to reconstruct "how actors engage with, interpret, appropriate or ignore the dynamics of European integration" (Woll and Jacquot, 2010: 118), whose macro-implications regarding the EMU have been explicated above.

Faced with the apparent contradiction between theory and practice in the field (or between "talk" and "action"), the study on which this article is based first attempted to reconstruct the positions of European-level sectoral federations and national sectoral trade unions on wage coordination from their programmatic publications. These insights were subsequently contrasted with findings from half-standardised expert interviews conducted with trade union officials between October 2013 and June 2014. During the course of the study, a total of eighty-eight interviews were conducted, twenty of them with actors directly involved in European wage coordination. Of those, eight were members of the German national organisations IG Metall and ver.di, and seven were members of European sectoral federations (five in IndustriALL and two in the European Federation of Public Service Unions. The selection of interview partners from the German national organisations reflects the division of labour within those organisations: all of the interviewees were professionally involved in collective bargaining. Two were experts from the unions' Tarifabteilungen (collective bargaining departments), which are responsible for collective bargaining policy, while the other five worked as Tarifsekretäre (collective bargaining secretaries) at IG Metall locals, in which capacity they were responsible for implementing the regional collective bargaining agreement. By including representatives from the local, national and European level, the case study covers all levels of the European trade union system. In order to complement this internal knowledge with external perspectives, two representatives from the German Trade Union Confederation, two from the European Trade Union Confederation (ETUC), one from the

Föderationen Tjänstemännens Centralorganisation and one from the Austrian Produktionsgewerkschaft were also interviewed.

\section{Wage Coordination under the EMU: Empirical Findings}

\section{The transformation of German capitalism and its impact on collective bargaining}

This section aims to illustrate the meso-level framework conditions for collective bargaining within the German political economy in general, and the German metal sector in general. The relationship between the economy and society in Germany has traditionally been referred to by such terms as Social Partnership (Müller-Jentsch, 2009), Coordinated Market Economy (Hall and Soskice, 2001) or Rhineland Capitalism (Albert, 1992), all of which emphasise the "social dimension" of this relationship, especially in comparison to the more liberal economic model of the United States. 
However, recent developments have led a range of scholars to conclude that this model has changed fundamentally in recent decades.

These developments are reflected in the trend of moderate wage growth, which lags behind the rate of inflation and productivity growth. In 2014, Germany was the only EU country in which real wages were lower than they had been a decade earlier (Schulten and Bispinck, 2014). Furthermore, increasing wage differentials between manufacturing and the service sector weakened horizontal coordination in the German wage-setting system. Three reasons for this trend can be identified.

First, trade union membership in Germany decreased by 12 per cent (i.e. 900000 members) between 2004 and 2014. Second, opening (or hardship) clauses, which under certain conditions allow management and works councils to conclude agreements that deviate from collective standards, gradually undermined the regulatory effect of collective bargaining agreements. As a result of the 2004 Pforzheim Agreement in particular, so-called hardship clauses enable management and works councils to leave the collective agreement. Such clauses have gradually become a regular feature of the German collective bargaining system (Haipeter, 2011). Third, in the early 2000s the Schröder government introduced the so-called Hartz reforms, labour market reforms that, by increasing the number of atypical employment relationships and reducing unemployment benefits, have weekend trade unions' bargaining power.

\section{Collective bargaining in Germany: findings from the metal sector}

Since the end of the Second World War, the metal sector has been at the heart of Germany's model of diversified quality production (Streeck, 1992). Foreign demand for high-quality goods ensures a high level of economic growth across the entire economy and fosters cooperative labour relations. As Höpner (2014a: 661) argues, "the export orientation of German industry is not only encouraged by the institutions of its production regime, but [is] also an integral part of its economic structure".

IG Metall has 2.3 million members in iron and steel, skilled crafts and trades, wood and plastics, metalworking and electrical, and textile industries, all of which are export industries. These sectors are particularly exposed to international competition, a fact that also affects IG Metall's representative work. According to Rüb (2009: 145), IG Metall is guided by the principle of productivism, which is characterised by the constant modernisation, rationalisation and innovation of companies and labour relations in order to ensure economic growth and labour's participation in societal wealth. One of the core principles of productivism, according to Rüb (2009: 146) is ensuring that the export economy remains competitive. While almost 60 per cent of all German exports are sold within the EU, the figure for the metal sector is even higher (IG Metall, 2014).

Collective bargaining in the metal sector has been shaped significantly by this trend toward decentralisation. While the Pforzheim Agreement has resulted in a significant shift in bargaining to the company level, IG Metall's headquarters in Frankfurt am Main maintains an important role in collective bargaining, as Rüb (2009: 136) demonstrates. Collective bargaining has also been affected by the Hartz reforms (Hassel and Schiller, 2010), which have expanded the low-wage sector and decreased labour costs by increasing precarious labour (including part-time and temporary employment through, for example, service contracts) (Palier, and Thelen, 2010).

Wage developments in the German metal sector demonstrate that the Golden Rule is not being met. On average, between 1998 and 2013 the sector trailed the national inflation rate by 2.9 percentage points and the EU inflation rate by 3.4 percentage points (see Table 1). 
Table 1: Wage development in the German metal sector, 1998-2013

\begin{tabular}{|c|c|c|c|c|c|c|c|c|c|c|c|c|c|c|c|c|c|}
\hline & 98 & 99 & 00 & 01 & 02 & 03 & 04 & 05 & 06 & 07 & 08 & 09 & 10 & 11 & 12 & 13 & \\
\hline $\begin{array}{l}\text { ECB inflation rate } \\
\text { (ECBR) }\end{array}$ & 2 & 2 & 2 & 2 & 2 & 2 & 2 & 2 & 2 & 2 & 2 & 2 & 2 & 2 & 2 & 2 & \\
\hline $\begin{array}{l}\text { National inflation } \\
\text { rate (NR) }\end{array}$ & 1 & 0.6 & 1.4 & 2 & 1.1 & 1.6 & 1.6 & 1.5 & 1.5 & 2.3 & 2.6 & 0.3 & 1.1 & 2.1 & 2 & 1.5 & \\
\hline $\begin{array}{l}\text { Economic } \\
\text { productivity }\end{array}$ & 5.1 & $*$ & 10.1 & 2 & 1.9 & 2.2 & 4.0 & 4.8 & 6.4 & 5.1 & -0.3 & -11.9 & 10.4 & 5.9 & -1.9 & -0.7 & \\
\hline $\begin{array}{l}\text { Outcome according } \\
\text { to wage rule with } \\
\text { ECBR }\end{array}$ & 7.1 & 2.6 & 12.1 & 6 & 3.9 & 4.2 & 6 & 6.8 & 8.4 & 7.1 & 2 & 2 & 12.4 & 7.9 & 2 & 2 & \\
\hline $\begin{array}{l}\text { Outcome according } \\
\text { to wage rule with NR }\end{array}$ & 6.1 & $*$ & 11.5 & 6 & 3 & 3.8 & 5.6 & 6.3 & 7.9 & 7.4 & 2.6 & 0.3 & 11.5 & 8 & 2 & 1.5 & \\
\hline Initial demand & & 6.5 & 5.5 & & 6.5 & & 4 & & 5 & 6.5 & & 8 & & & 6.5 & & \\
\hline Outcome & 2.5 & 3.2 & 3 & 2.1 & 3.1 & 2.6 & 1.5 & 2 & 3 & 4.1 & 2.1 & 2.1 & 0 & 2.7 & 4.3 & 3.4 & \\
\hline Deviance from ECBR & -4.6 & $*$ & -9.1 & -3.9 & -0.8 & -1.6 & -4.5 & -4.8 & -5.4 & -3 & 0.1 & 0.1 & -12.4 & -5.2 & 2.3 & 1.4 & -3.4 \\
\hline Deviance from NR & -3.6 & $*$ & -8.5 & -3.9 & 0.1 & -1.2 & -4.1 & -4.3 & -4.9 & -3.3 & 0.5 & 1.8 & -11.5 & -5.3 & 2.3 & 1.9 & -2.9 \\
\hline
\end{tabular}

* no data available

\section{Dynamics of European wage coordination in the metal sector}

We now turn to the micro-dynamics of European wage coordination in the German metal sector. While bargaining coordination initiatives began in the 1970s, they received a renewed impetus in the early 1990s through the creation of the EMF's Collective Bargaining Committee. And while bargaining coordination had traditionally been the responsibility of the trade unions' international secretaries, this new initiative was pioneered by representatives from national union federations' collective bargaining departments. ${ }^{7}$ With "real bargainers coming to the international front", as one Swedish representative who took part in starting the initiative explained in an interview, the new working group - according to a representative from IndustriALL - reflected the new political salience of bargaining coordination. With no formal competence in collective bargaining at the European level, the initial idea of this group was to stimulate further Europeanisation by making some aspects of international cooperation obligatory.

Today, according to IG Metall's (2005: 21) public relations material, wage coordination is more than an abstract goal. Similarly, IndustriALL (2015) placed "wage increases that meet the inflation rate and a balanced distribution of productivity gains" at the core of its "Political Resolution 2011-2015". Many of the unions' publications describe the main goal as avoiding downward competition, and they only mention macroeconomic stability in passing, if at all (IG Metall, 2006: 4). This programmatic orientation was underlined by representatives from two regional collective bargaining departments directly involved in collective bargaining. They stated that coordination is not a "guideline" but a "rule", and that it has to be measured by actual "facts

\footnotetext{
${ }^{6}$ The listed outcomes reflect wage growth, based on an aggregate of all regional bargaining negotiations. One-time bonuses are not included in these numbers as these usually increase workers' income, and the actual redistribution might be more favourable to labour than these numbers make it appear. Calculations are based on data taken from the Tarifarchiv provided by the Hans Böckler Foundation (2018), especially Appendix 1. Data on productivity growth was taken from the German metal-sector business association Gesamtmetall (2015). The table is based on the author's own calculation.

7 The northwestern European bias of this pioneering group, which consists of five representatives each from Germany, Austria, Sweden and Belgium, is clear. One of the German representatives explained this bias as resulting from the fact that the EMF's working language is English, which labour representatives from other EU countries are generally not as competent in.
} 
and numbers". In line with Brunsson (1989), therefore, we can detect a clear commitment on the part of IG Metall to wage coordination.

Actual EU-level wage coordination in the metal sector today is mostly carried out by IndustriALL. In accordance with the guidelines formulated at its collective bargaining conferences, ${ }^{8}$ the various national member organisations delegate representatives to its Collective Bargaining Committee. While IndustriALL formulated the Golden Rule, its role is limited to acting as a common forum in which policies can be determined and implemented. Outcomes of the national bargaining rounds are discussed by representatives. Instead of coordinating demands in national bargaining rounds in advance, the federation limits itself to an ex post discussion and leaves enforcement of collective agreements to national affiliates. All members are required to report their bargaining outcomes to the Eucob@n database. On the basis of the data collected there, a systematic comparison of the outcomes can serve as an instrument for soft sanctions in the form of "naming and shaming" in the case of non-adherence. Since the mid-1990s, the federation has (unsuccessfully) attempted to transcend this limited role to its "appellative character" (Henning, 2013: 245).

This lack of assertiveness translates into what all representatives describe as a persistent national focus in collective bargaining. As one of the regional bargainers from IG Metall confirmed, the European frame of reference is not important in bargaining rounds:

Europe is not as visible as you might think from the brochures or you might imagine in reality. As I said, there is no one sitting in a back room with their European computer open typing things in and saying what is allowed and what isn't. It's more the case that we say this is something we have to justify, this is something we have to include. But in my day-to-day work, it's not as though I have a wage round 2015 folder with a section on Europe.

As his colleague from another regional bargaining department explained, neglecting the wagecoordination rule thus stems not only from internal reluctance, but also - and more importantly from the interests of their members:

These references to Europe don't play a big role when we're negotiating, especially in our public relations. You can't go on strike and say, 'We're doing this for our European friends'.

Apart from these considerations, an IG Metall international secretary pointed to structural barriers to explain why they do not push for wage coordination:

How's it supposed to work? We don't have a recipe, and we've really tried over the last few years. ... The differences between wage-setting systems make it impossible. We can't do this the way we'd planned.

The reluctance regarding European wage coordination is also visible in the failure to collect appropriate statistical data. As IG Metall (2011: 10) states in a publication, there is no harmonised documentation to enable a detailed comparison of national bargaining outcomes. Moreover, the delegation of representatives meant to ensure mutual monitoring has been disbanded. Finally, as stated by IndustriALL (2012), national representatives' lack of reliability in submitting the necessary data demonstrates that there is a major discrepancy between words and actions.

\footnotetext{
${ }^{8}$ Since the 1990s, seven such conferences have been held - Luxemburg (1993), Brussels (1996), Frankfurt am Main (1998), Oslo (2001), Rome (2005), Madrid (2009) and Vienna (2014).
} 
Asked about this discrepancy, the representatives emphasised the programmatic character of the initiative:

I think it's important that we make clear what we want. And if some things don't work in our everyday cooperation, there are no bad intentions behind this or neglect or anything like that.

Another member of the working group pointed to the effect of the initiative on general debates regarding European wage policy. "Developing such a programme is great in the sense that we're having a discussion, at least." For him, the Golden Rule is not "like a grindstone around my neck" (i.e. a binding requirement), but a "shared idea that creates a community".

In such a context, bargaining coordination loses its material component. When asked about the lack of practical implementation, these representatives shift the emphasis from preventing downward competition to an abstract claim for the need for wage coordination. Since the initiative has not led to the results they had hoped for, they have shifted the goal.

After being asked about the failure to collect the necessary data to pursue bargaining coordination, one of the regional bargaining secretaries explained an essential heuristic of his representative work: a distinction between the theoretical framework for bargaining coordination and actual practice. In this context, the lack of comparable national data does not pose a practical problem:

Of course, a researcher interested in comparing sectors or national economies would have problems if there was no comparable data. But for us as practitioners, the wage rule serves to protect us from even greater competition. So everyone is reminded to use the national space for negotiation.

The other regional bargainer agreed:

Reality is more complex than any armchair reasoning, even if it's scientifically rigorous or theoretically desirable.

The interviewees use this distinction between theory and practice to rationalise non-adherence to the bargaining rule. At the same time, theory does not lose its significance, but its significance changes:

If I just look at the practice and don't care about a bigger shared idea, it's also not going to work. It's this tension that makes things interesting. I can't just move on one side: I need to look at the entire field.

In order to explain the seemingly stagnant state of international bargaining coordination, the representative of IndustriALL drew on an analogy between the emergence of trade union structures at the national level and current developments:

And that means we can learn from it [national-level history]. You can't just copy it either, that's also true. But you have to learn from it. And to me, that incremental aspect is important, because you also need to learn to adapt something that is also historically proven.

Since local trade unions merged into national organisations in the course of modernisation and state-building, although they were not originally intended to do so, this representative concluded that the same development is likely to unfold in the course of European integration. On this basis, 
he argued, a relocation of collective bargaining competencies to the European level would be appropriate:

That's a gradual change of local scales, meaning the national organisations, which are saying, 'We need more than simple meeting places, more than the social company of other trade unions. We need to set up some structure to try to establish some things.' I wouldn't deny the problems, but it would also be wrong to only highlight the difficulties without seeing that this is a natural evolution. And you can't expect evolution to happen quickly.

By declaring that bargaining coordination is a long-term project, the representative makes clear that, from his perspective, the perpetual discrepancy between actual bargaining outcomes and the Golden Rule does not constitute a fundamental problem. On the contrary, it points to the need to further empower European-level federations. While binding legal regulations do not exist "at the moment", they could, he explains, be aspired to in the long run. He describes this approach as "working towards the future and guiding it". Current wage-coordination initiatives therefore, according to him, serve to establish a future European arena - and not to coordinate wages in the present.

\section{Summary}

Bargaining outcomes demonstrate that the talk and actions of trade unions differ. The results show that a discrepancy between the general statement that wages under the EMU should be pegged to inflation and productivity and actual outcomes of the bargaining rounds within the inquired timeframe of fifteen years is at the core of the coordination initiative maintained between IG Metall and IndustriALL. Moreover, it seems remarkable that even some basic preconditions for wage coordination, such as comparable data, are not being met. Therefore, in reality, the trade unions' actions do not effectively serve to coordinate wages. To be precise, what is being coordinated between the two organisations is wage demands. Coordinating wage demands is surely a necessary step in the process of coordinating wages. However, the fact that IG Metall's demands mostly equal, or in some cases only slightly exceed, the wage increase necessary to meet the coordination rule does raise the question as to which trade union manages to push through its initial bargaining demands over fifteen years in a row.

So why have trade unions been engaging in wage coordination for all this time, even though they obviously never reach their (nominal) goal of even wage development? With regard to the four explanations drawn from the literature - interests, ideas, normative pressure and internal subgroups - we find that all play a role as explanatory factors. While members' and representatives' interests in remaining competitive force national collective bargainers to neglect the Golden Rule (interest-based explanation), they are not only independently aware of their international responsibility (identity-based explanation), but also constantly reminded of that responsibility by European-level organisations (normative explanation). Furthermore, IndustriALL representatives are responsible for the international coordination of the collective bargaining sector (sub-groupbased explanation). In order to combine these four potential motives and thus understand the dynamics behind the constant failure of wage-coordination initiatives, two theoretical positions have been integrated into an action-theoretical model - pragmatism and neo-institutionalism.

Informed by these theoretical realms, we find that the trade unionists involved in bargaining coordination have over time engaged in what can be understood as a creative reinterpretation of the coordination initiatives. From their perspective, adherence to the rule is neither possible (they 
do not have enough bargaining power) nor desirable (it is not in their members' interests), and it would - due to non-adherence in other EMU countries (institutional heterogeneity) - not have the desired effect. Accordingly, representatives have long become comfortable with not adhering to the Golden Rule. Their understanding of the meaning of bargaining coordination has changed over time, and the material component has been replaced by a programmatic notion. This reinterpretation enables IG Metall to follow several incoherent orientations at the same time: Firstly, they can maintain their competitiveness in an international market. Secondly, they can practice rituals of international solidarity and thus adhere to the values of international trade unionism as well as external expectations from other trade union organisations. And thirdly, they can maintain their agency on an international level through keeping up the core business of their European-level representative work.

Viewed through an action-theoretical lens, this third point seems particularly remarkable. The fact that IG Metall has not been able to meet its stated goal does not mean that its representatives are not actually trying to achieve it. What, from an external perspective, may seem like a systematic hoax is, from the perspective of the actors involved, the preliminary outcome of an ongoing struggle. That someone wants to achieve a goal does not necessarily mean that they can do so immediately, but neither does it mean that they will never be able to do so. In order to develop the capacity to coordinate wages effectively, such initiatives must be maintained in the present. Or, to put it more critically, present failure is rationalised through future success. Maintaining their coordination initiatives despite the fact of nominal failure leaves IG Metall enough space to manoeuvre according to these three logics.

\section{Outlook}

This study has examined the persistence of EMU-wide wage-coordination initiatives even under fundamentally adverse conditions. But what does all of this mean for the process of European integration in toto? As John Dewey (1991: 27) has stated, "[T] he formation of states must be an experimental process". From such a perspective, symbolic ideas about the future of the EU are of central importance "in the sense that novel institutions do not emerge ex nibilo" (Sabel and Zeitlin, 2012: 423): if national trade unionism developed as a bottom-up movement, why should the same not be possible for European trade unionism as an integral part of a European state backed up by a common currency?

As could be shown, labour representatives establish a future narrative by drawing from the past (the development of the nation-state and the labour movement). By referring to this future state in which adherence may be possible, the political goal of avoiding downward competition and maintaining macroeconomic stability does not have to be abandoned. From a political economy perspective, however, things appear more ambivalent. Because Germany's foreign trade balance has not only perpetuated but also worsened the macroeconomic disequilibrium that has significantly contributed to the current EU crisis (Scharpf, 2014), labour costs in the export sector remain a key factor in this constellation. If this does not change, the situation will not only not improve, but will likely get worse, especially in the context of fiscal austerity and the consequent lack of economic growth resulting from overall wage increases.

If trade unions maintain their agency on an international level by creatively muddling through, the challenge may seem remarkable in itself. At the same time, the reinterpretation of the Golden Rule as a future aspiration connected to the creation of a European Social Model established to reconcile capitalism and democracy within the EU could therefore at the very same time serve to 
rationalise an integration project that has grown out of control. Understanding these issues better must be the task of further research.

\section{REFERENCES}

Albert, Michael (1992) Kapitalismus contra Kapitalismus. Frankfurt am Main and New York: Campus.

Ansell, Chris (1997) Symbolic Networks: The Realignment of the French Working Class, 1887-1894. American Journal of Sociology, 103(2): 359-390.

Ansell, Chris (2011) Pragmatist Democracy. Oxford: Oxford University Press.

Brunsson, Nils (1989) The Organization of Hypocrisy. Hoboken, NJ: John Wiley \& Sons.

Dewey, John (1991) The Public and Its Problems. Athens: Ohio University Press.

Erne, Roland (2008) European Unions. Ithaca, NY: Cornell University Press.

Flassbeck, Heiner and Costas Lapavitsas (2015) Nur Deutscbland kann den Euro retten: Der letzte Akt beginnt. Frankfurt am Main: Westend.

Flassbeck, Heiner and Friederike Spiecker (2010) Lohnpolitische Konvergenz und Solidarität oder offener Bruch. Wirtschaftsdienst, 90(3): 1-7.

Gesamtmetall (2015) Lange Zeitreihen. http://www.gesamtmetall.de/gesamtmetall/meonline.nsf/ id/PageJahreszahlen-in-langen-Zeitreihen_DE (accessed 3 March 2015).

Glassner, Vera (2009) Two Paths towards Europeanisation. PhD thesis, Universität Wien, Austria.

Glassner, Vera and Susanne Pernicka (2014) Transnational Trade Union Strategies towards European Wage Policy. European Journal of Industrial Relations, 20(1): 1-18.

Glassner, Vera and Philippe Pochet (2011) Why Trade Unions Seek to Coordinate Wages and Collective Bargaining in the Eurozone. Working Paper 3/2011. Brussels: ETUI.

Haipeter, Thomas (2011) Einleitung. In Gewerkschaftliche Modernisierung, edited by Thomas Haipeter and Klaus Dörre. Wiesbaden: VS.

Hall, Peter A. (2007) The Evolution of Varieties of Capitalism in Europe. In Beyond Varieties of Capitalism, edited by Bob Hancké, Martin Rose and Mark Thatcher. Oxford: Oxford University Press.

Hall, Peter A. and David Soskice (2001) Varieties of Capitalism. Oxford: Oxford University Press.

Hancké, Bob (2013) Unions, Central Banks and EMU. Oxford: Oxford University Press.

Hancké, Bob (2014) Employment Regimes, Wage Setting, and Monetary Union in Continental Europe. In The Oxford Handbook of Employment Relations: Comparative Employment Systems, edited by Adrian Wilkinson, Geoffrey Wood and Richard Deeg. Oxford: Oxford University Press.

Hans Böckler Foundation (2018) WSI Tarifarchiv. http://www.boeckler.de/index_wsi_tarifarchiv.htm.

Hassel, Anke and Christof Schiller (2010) Der Fall Hartz IV: Wie es zur Agenda 2010 kam und wie es weitergebt. Frankfurt and New York: Campus.

Henning, Klaus (2013) Europäische Integration und Gewerkschaften. Wiesbaden: Springer.

Hernes, Tor (2014) A Process Theory of Organizations. Oxford: Oxford University Press.

Höpner, Martin (2013) Die Verschiedenheit der europäischen Lobnregime und ibr Beitrag zur Eurokrise. Discussion paper 13/5. Cologne: MPIfG.

Höpner, Martin (2014a) Europe would be better off without the Euro. Labour History, 55(5): 661-666.

Höpner, Martin (2014b) Transnationale Lohnkoordination in einem System fester Wechselkurse. WSIMitteilungen, 4: 317-319. 
Höpner, Martin and Mark Lutter (2014) One Currency and Many Modes of Wage Formation. Discussion paper 14/14. Cologne: MPIfG.

Höpner, Martin and Martin Seeliger (2017) Transnationale Lohnkoordinierung zur Stabilisierung des Euro? Gab es nicht, gibt es nicht, wird es nicht geben. Cologne: Max-Planck-Institut für Gesellschaftsforschung.

Horn, Gustav, Fabian Lindner and Sabine Stephan (2017) The Role of Nominal Wages in Trade and Current Account Surpluses. Düsseldorf: IMK.

Hyman, Richard (2002) Where does Solidarity End? Eurozine. Quelle. http://www.eurozine.com/pdf/200209-17-hyman-en.pdf (accessed 24 September 2018).

IG Metall (2005) Europäische Koordinierung nationaler Tarifpolitik. Frankfurt am Main: IG Metall.

IG Metall (2006) Für ein solidarisch ernemertes Europa. Berlin: IG Metall.

IG Metall (2011) Wirkung der Koordinierungsregel des EMB. Frankfurt: IG Metall.

IG Metall (2014) Das Soziale Europa. Frankfurt: IG Metall.

IndustriALL Europe (2012) Political Resolution 2011-2015. Brussels: IndustriALL.

Joas, Hans and Jens Beckert (2001) Action Theory. In Handbook of Sociological Theory, edited by Randal Collins. Wiesbaden: Springer.

Johnston, Alison (2009) Wage Policy in Austria and the Netherlands under EMU. Working Paper 7/2009. Brussels: ETUI.

Krassner, Stephen D. (1999) Sovereignty: Organized Hypocrisy. Princeton: Princeton University Press.

March, Johan and Johan Olsen (1979) Ambiguity and Choice in Organizations. Bergen: Universitetsforlaget.

Marginson, Paul and Keith Sisson (2004) European Integration and Industrial Relations. New York: Palgrave Macmillan.

Mead, George Herbert (1934) The Social Foundations and Functions of Thought and Communication. In Mind, Self and Society from the Standpoint of a Social Behaviorist, edited by Charles W. Morris. Chicago: University of Chicago Press.

Meyer, John W. and Brian Rowan (1977) Institutionalized Organizations: Formal Structure as Myth and Ceremony. American Journal of Sociology, (83): 340-363.

Müller-Jentsch, Walther (2009) Arbeit und Bürgerstatus. Wiesbaden: VS.

Overdevest, Christine (2011) Towards a More Pragmatic Sociology of Markets. Theory \& Society, 40: 533 552.

Overdevest, Christine and Jonathan Zeitlin (2012) Assembling an Experimentalist Regime. Regulation \& Governance, 8(1): 22-48.

Palier, Bruno and Cathlene Thelen (2010) Institutionalizing Dualism - Complementarities and Change in France and Germany. Politics \& Society, 38(1): 119-148.

Pen, Jan (1964) Europäische Lohnpolitik. Gewerkschaftliche Monatshefte, 14: 581-585.

Pernicka, Susanne and Vera Glassner (2014) Transnational Trade Union Strategies towards European Wage Policy. European Joumal of Industrial Relations, 20(1): 1-18.

Platzer, Hans-Wolfgang (2002) Europäisierung und Transnationalisierung der Arbeitsbeziehungen in der EU. Internationale Politike und Gesellschaft, 2: 103-121.

Risse, Thomas (2004) Global Governance and Communicative Action. Government and Opposition, 39(2): 288313.

Rüb, Stefan (2009) Die Transnationalisierung der Gewerkschaften. Berlin: Sigma.

Sabel, Charles F. and Jonathan Zeitlin (2012) Experimentalism in the EU. Regulation \& Governance, 6(3): 410 426. 
Scharpf, Fritz W. (2014) No Exit from the Euro-Rescuing Trap? Discussion paper 14/4. Cologne: MPIfG.

Schulten, Thomas (2001) Solidarische Lohnpolitik in Europa. Discussion paper 92. Düsseldorf: WSI.

Schulten, Thomas (2004) Solidarische Lobnpolitik in Europa. Hamburg: VSA.

Schulten, Thorsten and Reinhard Bispinck (2014) Wages, Collective Bargaining and Economic Development in Germany. Discussion paper 191. Düsseldorf: WSI.

Schulten, Thorsten and Torsten Müller (2013) Ein neuer europäischer Interventionismus? Wirtschaft und Gesellschaft, 39(3): 291-320.

Sinn, Hans Werner (2015) Der Euro. Von der Friedensidee zum Zankapfel. München: Carl Hanser.

Streeck, Wolfgang (1992) Social Institutions and Economic Performance. London: Sage.

Streeck, Wolfgang (1999) The Organization of Business Interests: Studying the Associative Action of Business in Advanced Industrial Societies. Discussion paper 99/1. Cologne: MPIfG.

Streeck, Wolfgang (2005) The Sociology of Labor Markets and Trade Unions. In The Handbook of Economic Sociology, edited by Neil J. Smelser and Richard Swedberg.. Princeton: Princeton University Press.

Streeck, Wolfgang (2015) Gekaufte Zeit. Berlin: Suhrkamp.

Traxler, Franz (2000) Das Tarifverhandlungssystem in der Wirtschafts- und Währungsunion. Kölner Zeitscbrift für Soziologie und Sozialpsychologie. Sonderbeft, 40: 93-111.

Traxler, Franz and Bernd Brandl (2009) Towards Europeanization of Wage Policy. European Union Politics, 10(2): 177-201.

Watt, Andrew (2011) Economic Governance in Europe in the Wake of the Crisis. Transfer, 17(2): 255-261.

Webster, Edward, Rob Lambert and Andries Bezuidenhout (2008) Grounding Globalization: Labour in the Age of Insecurity. London: Blackwell.

Woll, Cornelia and Sophie Jacquot (2010) Using Europe: Strategic Action in Multi-level Politics. Comparative European Politics, 8(1): 110-126.

\section{BIOGRAPHICAL NOTE}

MARTIN SEELIGER, assistant professor at Europa-Universität Flensburg, wrote his doctoral dissertation on European Trade Unionism at the Max Planck Institute for the Study of Societies in Cologne. He studied social science in Bochum and was a visiting fellow in Mexico City, Johannesburg, Stockholm, Jerusalem, Berkeley, Jena and Brussels, where he did research in the field of economic sociology, political economy and cultural studies, mainly informed by elements of American Pragmatism and Sociological Institutionalism. [Email: martin.seeliger@gmx.net] 